\title{
CONTEMPORARY EUROPEAN CULTURAL VALUES IN THE CONTEXT OF AXIOLOGY OF SUSTAINABLE DEVELOPMENT
}

\author{
Aleksandra KUZIOR \\ Silesian University of Technology, Faculty of Organization and Management, Department of Applied Social \\ Sciences, Zabrze, Poland; Aleksandra.kuzior@polsl.pl, ORCID: 0000-0001-9764-5320
}

Purpose: The purpose of the article is to present the issues of cultural values of modern Europe in reference to their ancient sources (Plato, Aristotle), as well as to indicate correlations between the value of European culture and the axiology of sustainable development.

Design/methodology/approach: The article is based on a critical analysis of the literature on the subject. It presents in detail the issues of justice and responsibility, indicating Europe as a "community of responsibility". Justice is considered as a moral, legal and economic value, taking into account the generation and intergenerational perspective, as well as community and individual value. Responsibility, as in the case of justice, is shown in relation to the present and future generations. The subject and object of responsibility were defined and the main relational references of this moral and legal value were characterized. The article also refers to the basic documents constituting the concept of sustainable development.

Findings: The analysis of the assumptions of the concept of sustainable development showed that in the concept, it can be seen that justice and responsibility are two basic values that are mutually conditioning and constitute the basis for the actual implementation of the assumptions of the concept of sustainable development, improvement of people's quality of life and ensuring security in its various dimensions.

Originality/value: The article is addressed to a wide range of readers who deal with the practical implementation of the assumptions of the concept of sustainable development. The article can also provide a didactic background for teaching social subjects and humanities. There is an original approach to ethical values in the context of the assumptions of the concept of sustainable development.

Keywords: sustainable development, axiology of sustainable development, values of European culture, justice, responsibility.

Category of the paper: Research paper. 


\section{Introduction}

The genesis of the concept of sustainable development is associated with such important events and activities as: the study on the condition of the environment and the famous $U$ Thant Report (1969), Reports for the Roman Club (among them the first two, which had a great impact on shaping the concept of sustainable development, i.e. Limits of growth (Meadows et al., 1972) and Humanity at a turning point (M 1974)), Stockholm Conference on Man and the Environment (1972), Conference in Rio de Janeiro (1992), Johannesburg Conference (2002), Conference in Rio de Janeiro (2012), Sustainable Development Summit in New York (September 2015). Among the documents constituting the concept of sustainable development there are: Stockholm Declaration (1972), Rio Declaration (1992), Agenda 21 Global Action Program (1992), Johannesburg Declaration (2002), Johannesburg Plan of Implementation (2002), Final document RIO + 20 - The future we want (2012), New Agenda for Sustainable Development 2030 (2015). In parallel to the activities of the UN and its subordinate agencies and the activities of the Roman Club, scientific reflection was developing, raising issues of environmental degradation and human condition in the world. Examples include publications such as Hans Jonas. Many definitions of sustainable development also appear in numerous publications and documents. Two of them deserve special attention. A 1975 definition of UNEP (United Nations Environment Program) that indicates that sustainable development is "such a course of inevitable economic development that would not significantly and irreversibly harm the human life environment, would not lead to the degradation of the biosphere that would reconcile the laws of nature, economics and culture" (Kozak, 1999, p. 257) and the definition of Brundtland Report (Our Common Future, 1987, p. 67) indicating that Sustainable development" is development that meets current needs without jeopardizing the possibilities of meeting the needs of future generations. "It is based on two basic concepts: the concept of "needs", and the concept of "limitations". The Brundtland report has significantly contributed to the popularization of the concept of sustainable development. The popularity of this idea, however, has not quite translated into practical actions, although they are undertaken by various governmental and non-governmental organizations and individually by specific people. Nevertheless, the multi-faceted environmental and humanitarian problems have still not been resolved, and some are even gaining momentum, as in the case of the greenhouse effect. The concept of sustainable development is anthropocentric, the value of the natural environment is not important per se, but precisely because of the possibility of human survival on earth - a planet that is home (oikos) to man. 


\section{Axiology of sustainable development and the values of European culture}

The anthropocentric orientation of the concept of sustainable development draws attention to the various values of man and human communities. Analysis of reports, studies and documents constituting the concept of sustainable development has shown that the values that play a significant role in the concept of sustainable development include: justice, responsibility, freedom, dignity, democracy, life and quality of life, security, environment (Kuzior, 2014).

European culture values can be classified as follows:

1. Truth, goodness, beauty and Good- the sphere of absolute values.

2. Life, freedom, dignity - the sphere of personal values.

3. Family, community, religion - the sphere of community values.

4. Pluralism, democracy, tolerance (sphere of community values) ( $\dot{Z} u k, 2016$, p. 116).

This classification can be supplemented by adding values that are important from the point of view of upbringing: altruism, tolerance, responsibility, freedom, justice (Lobocki, 2005, p. 108-118). These values can be included both in the sphere of community values and personal values.

It is not difficult to notice that the listed values of European culture and sustainable development concepts are mostly the same. This article will discuss in detail two of them: justice and responsibility. According to the author, these are absolutely basic values that condition all other values of European culture and the concept of sustainable development.

Certainly, the values of modern European culture arise from ancient roots. They should be looked for, among others in the Platonic theory of virtues, which includes such specific virtues as: prudence (sophrosyne) of self-control, bravery (andreia), wisdom (sophia) and justice (ikaiosyne), which is integrating the above virtues (Hessen, 1968; Żuk, 2005, p. 96). Plato adopted the Pythagorean concept of virtue, understood as order and harmony of the soul. The soul was divided into a rational, impulsive and lustful part. A specific virtue was fitted to each part of the soul. And so wisdom was the virtue of the rational part, bravery of the impulsive part, and self-control over the lust part. It was similar with body parts that were assigned to the appropriate virtues: wisdom - head, bravery - torso, abstinence - abdomen (Tatarkiewicz, 1988, pp. 98, 118-119). These relationships and connections are characterized by the diagram below. 




Figure 1. Justice, Source: own elaboration based on Tatarkiewicz, 1988.

In Plato's concept, justice is a value that integrates other virtues, but the philosophical tradition provides us with a different understanding of justice. Theorists dealing with the phenomenon of this value (virtue) include the already mentioned Plato and his student Aristotle, followed by Hume, Rousseau, Rawls, Nozick and MacIntyre. Justice is also one of the basic values in the concept of sustainable development. Its various aspects are illustrated in the diagram below.



Figure 2. Justice in the concept of sustainable development, Source: own elaboration (Kuzior, 2014, p. 63).

Justice can be considered simultaneously from an ethical and legal perspective. This is justified because morality and law condition each other (or at least they should). Mutual legal references are strongly emphasized in the concept of sustainable development. Analysis of the basic documents constituting the concept of sustainable development allows to list two main types of justice: 
1. Intergenerational justice.

2. Generational justice (intra-generational).

As part of generational justice, the concept of sustainable development distinguishes justice:

a) fungible,

b) distributive,

c) legal,

d) social,

e) international

f) global (Kuzior, 2008, pp. 333-339).

The concept of justice is also present in economics. Taking into account the assumptions of ecological economy, based on the foundation of the so-called strong durability, more emphasis is placed on intergenerational justice. Ecological economy adopts strict conditions for environmental protection and preservation of its resources for future generations. Theoreticians of ecological economics understand sustainable development as limiting economic growth and socio-economic development in order to stop and counteract excessive degradation of the natural environment (Jeżowski, 2001, pp. 99-100). Analysis of documents has shown, however, that in relation to the concept of sustainable development, we cannot speak of an ecocentric approach to environmental protection, as proposed by ecological economics. However, an anthropocentric approach can be identified, which is closer to the approaches of environmental economics, which prioritizes intra-generational justice. Nevertheless, the concept of sustainable development also includes provisions regarding the rights and needs of future generations (Kuzior, 2008c, pp. 333-339). For example, the Rio Declaration states: "The right to development must be fulfilled so as to fairly combine the developmental and environmental needs of present and future generations". The definitions of sustainable development quoted at the introduction also emphasize this intergenerational aspect of justice. However, the Earth Summit in Johannesburg and documents signed by representatives of the governments of 193 countries of the world clearly indicate the importance of generational problems and recognize as a priority the eradication of poverty, indicate appropriate ways of implementing intra-generational justice, including establishing a fund of solidarity with the poor and hungry and improving the quality of life for people at local, regional, national and global level. The assumptions of the discussed concept in this area allow to identify the assumptions of social justice. At the core of justice understood in this way is the value of interpersonal solidarity and solidarity. The idea of helping the needy and poor based on redistribution is therefore also rooted in other values that result from the fact that man is responsible for another man (Kuzior, 2008c, pp. 333-339). In the final document of the RIO + 20 conference, social justice manifests itself in supporting democracy and shaping a just society based on fair economic growth, including the creation of decent jobs, fair management and 
equitable distribution of benefits, and social development aimed at eliminating poverty, poverty and hunger, based on universal health care and social protection as well as equal opportunities and non-discrimination (The future we want, 2012). Another manifestation of social justice, included in the concept of sustainable development, is international economic justice, which refers to justice based on redistribution related to the elimination of poverty, hunger and malnutrition. In this case, however, the subject of entitlement changes. In the previous case, it was every human being that needed help, now underdeveloped countries are becoming the subject of authority. As part of international economic justice, we can talk about compensatory justice, which is to ensure the prosperity of underdeveloped countries through economic assistance. The concept of sustainable development also includes obligations arising from restorative justice, understood as the obligation of the perpetrator to account for and compensate for harm and restitution of damage caused - such understanding we can find in the Rio Declaration. The concept of sustainable development can also identify references to distributive (distributive) and alternative justice (Kuzior, 2008c, pp. 333-339). Aristotle has already distinguished these two types of justice. The first of these concerned "the community (state, family, etc.) ensuring its members share in the common good" (Maciejewski, 2012, p. 10). In the concept of sustainable development, distributive justice is essential in the fight against poverty and hunger. In turn, legal justice can be defined as the basis for the types of justice discussed earlier. It regulates the attitude of citizens to the state and the state to the citizens, and in the concept of sustainable development also the attitude of individual states and institutions to international legal regulations. Is (should be) the guarantor of building the common good.

In the concept of sustainable development, justice is inseparably connected with responsibility, which allows these values to be considered complementary. In some axiological considerations, there are justifications that it is thanks to responsibility that the idea of justice can be realized (Ingarden, 2004, p. 168).

In the concept of sustainable development, responsibility is not only a (moral) value, but even the basic principle constituting the concept, creating a new paradigm - the paradigm of responsibility. This paradigm concerns both ex-post-facto liability (e.g. compensation in the form of compensation to victims) and responsibility for what is to be done (Kuzior, 2008b, pp. 88-96; Kuzior, 2006, pp. 67-72). In the classification of European culture values proposed at the outset, responsibility is a personal (individual) and community (collective) value. In the concept of sustainable development, a third type of responsibility is additionally highlighted - institutional responsibility. It is also worth paying attention to the relational nature of responsibility, i.e. for whom?, For what?, To what extent?, Based on what principles? and to whom? corresponds to the subject. In other words, what is the subject of responsibility and in what time and spatial perspective the subject's liability applies (should apply). 
These relationships are presented in diagram 3 and 4, taking into account the considerations of R. Ingarden (1987, 2004) and G. Ropohl (1999, pp. 93-107) as well as the author's own thoughts and statements regarding the concept of sustainable development.



Figure 3. Subject of responsibility., Source: own elaboration (Kuzior, 2014, p. 46). 




Figure 3. Subject of responsibility in the concept of sustainable development, Source: own elaboration (Kuzior, 2014, p. 47). 
Based on the analysis of the documents constituting the concept of sustainable development, it can be concluded that the subject of responsibility in the concept of sustainable development is very wide. The entity is responsible (for whom? What?) For the action and its effects, both positive and negative; is responsible for progress and development, for implementing the concept of sustainable development; is responsible for himself, for another human being, for a wider community of living beings, for the natural environment; is finally responsible for future generations, for the duration and development of life on earth. Therefore, we are dealing here with generational and intergenerational responsibility (Kuzior, 2014, p. 48). Responsibility for progeny, for future generations in the long term, opens up the issue of natural responsibility, which grows out of natural order, is global, independent and irrevocable, cannot be abandoned, there is a force of nature in which it is rooted (Jonas, 2004, p. 211). Contemporary technical civilization and related technological innovations (Kuzior, Zozul'ak, 2019), development of the Internet (Strbova, Kuzior, 2019), cognitive technologies and artificial intelligence (Kuzior et al., 2019; Kwilinski et al., 2019; Tkachenko et al., 2019; Kwilinski, Kuzior, 2020), Industry 4.0 (Fobel, Kuzior, 2019) reveal new dimensions of responsibility, both individual, collective and institutional, e.g. in the area of CSR (Orbik, Zozul'aková, 2019; Kuzior, Knosala, 2015). However, the basic relational scheme and direction of the subject's responsibility for the subject (and not vice versa) remains the same. Hypothetically, of course, you can reverse this relationship and make some object responsible for some wrong done to the subject, e.g. a defective car is the cause of an accident in which a person suffers permanent health damage or loses his life. Such an argument is, however, completely illogical, because behind the production of this car and components located in it stands a whole host of people, and de facto they are individually and the company that produced and sold the defective car is institutionally responsible. There is therefore a possibility of compensation for the damage suffered, whether directly to the injured party or his family.

In case of intergenerational responsibility, there is a certain problem of inability to redress if the effects of actions prove to be negative, e.g. the quality of life of future generations will significantly deteriorate due to errors and irresponsible actions of their fathers, or inaction that should be taken. The responsibility paradigm, indirectly defined in the concept of sustainable development, sets the direction and gives hope for life on earth and for the development of the homo sapiens species. However, a thorough reconstruction of consciousness is necessary. The Cartesian-Kantian paradigm of rationality that dominates in modern times must be extended to the emotional sphere, shaping a new approach to the world based on the paradigm of responsibility.

The problem of liability instances is also complex. One can speak of a legal, moral or religious instance of responsibility. In the documents constituting the concept of sustainable development, mainly a legal instance has a regulatory value. Under it, the institutional responsibility of states, institutions and enterprises assumes the dimension of expost-facto liability (damages, torts). Nevertheless, a moral instance is equally important, especially if we 
take into account care for the quality of life of future generations (Kuzior, 2014). Nicolai Hartmann defines responsibility for future generations with a beautiful metaphor for "love for the farthest". However, he indicates that we must realize our place in the chain of human development. Responsibility for future generations is one-way, one-sided. Always applies to the one who lives before. Epigoni are not responsible for their deceased ancestors. Responsibility for future generations is a diachronic process. The one who has been included in this responsibility has a new responsibility for future generations. Solidarity with future generations is manifested in this kind of responsibility. However, modern man still stuck in moral immaturity cannot bear such a burden (Hartmann, 2004, p. 44). Contemporary man has not grown up to take on responsibility for generations. The final document of the RIO +20 conference contains a rather pessimistic conclusion about poverty and famine in the world "one in five people, that is over 1 billion people, is still living in extreme poverty, and one in seven - that is $14 \%$ - is malnourished while public health challenges, including pandemics and epidemics, are still pervasive threats." How current these records are in the face of today's COVID-19 threat. In the global dimension, the situation of the poorest has only slightly improved, but the statistics are still terrifying. UN report: Famine still threatens millions of people in the world (2018) indicates that the number of starving people in the world in 2018 was 821.6 million (every 9th person in the world), and the number of people without food security is 2 billion (26,4\% of the world's population). Europe with its values is helpless and immersed in powerlessness or lack of solidarity with the poorest. Z. Bauman argued that the modern world needs a Europe with a sense of global mission. And in the assumptions Europe with its values is just that. The "European Identity Card" defines Europe as a "community of responsibility" (Bauman 2005, 57; Kuzior 2008a). However, Europe cannot bear this burden and is also in a crisis, including a crisis of values. For this reason, humanities education, including education to value, is important in the development of modern man (Zozulaková, 2018).

\section{Conclusion}

The above considerations lead to the conclusion that the values of European culture and the values of the concept of sustainable development are really based on the common roots of cultural heritage, which grew on Greek philosophy and Judeo-Christian tradition. These two sources of European culture played a significant role in shaping axiology and influenced the understanding of these values by subsequent generations. Their presence in the concept of sustainable development shows that they have become universal values, although nowadays they are understood and defined somewhat differently in different places around the world. The considerations leave no doubt, however, that the still current problems of environmental 
degradation, humanitarian and economic crises, epidemics and pandemics require continuous improvement of human beings in the scope of the described values of European culture, so that it is possible to effectively implement the assumptions of the concept of sustainable development and improve people's quality of life and ensure safety in its various dimensions.

\section{References}

1. Bauman, Z. (2005). Europa nieskończona przygoda [Europe. An Unfinished Adventure]. Kraków.

2. Deklaracja z Rio de Janeiro $w$ sprawie środowiska $i$ rozwoju [Rio Declaration on Environment and Development], http://www.mipe.oswiata.org.pl/rozwoj/doc/ deklaracja_z_rio.pdf.

3. Fobel, P., Kuzior, A. (2019). The future (Industry 4.0) is closer than we think. Will it also be ethical? AIP Conference Proceedings, 2186(1).

4. Hartmann, N. (2004). Miłość do najdalszych [Love for the farthest]. In: J. Filek (ed.), Filozofia odpowiedzialności XX wieku. Kraków.

5. Hessen, S. (1968). Cnoty starożytne a cnoty ewangeliczne (Uwagi o podstawach etyki starożytnej i nowoczesnej) [Ancient virtues and evangelical virtues (Remarks on the basics of ancient and modern ethics)] In: idem, Studia z filozofii kultury (pp. 194-268). Warszawa.

6. Ingarden, R. (1987). Książeczka o człowieku [A book about a man]. Kraków.

7. Ingarden, R. (2004). Ontyczne podstawy odpowiedzialności [Ontic basis of responsibility]. In: J. Filek (ed.), Filozofia odpowiedzialności XX wieku. Kraków.

8. Jeżowski, P. (2001). Nowe instrumenty ekonomiczne ochrony środowiska a sprawiedliwość wewnatrzgeneracyjna [New economic instruments for environmental protection and justice inside generational]. In: A. Pawłowski, M.R. Dudzińska (eds.), Zrównoważony rozwój w polityce i badaniach naukowych (pp. 99-100). Lublin.

9. Jonas, H. (2004). Teoria odpowiedzialności: podstawowe rozróżnienia [Theory of responsibility: basic distinctions]. In: J. Filek (ed.), Filozofia odpowiedzialności XX wieku. Kraków.

10. Kozak, Z. (1999). O pojęciach rozwoju zrównoważonego i ekorozwoju [On the concepts of sustainable development and eco-development]. In: J.M. Dołęga, J.W. Czartoszewski (eds.), Ochrona środowiska w filozofii i teologii. Warszawa.

11. Kuzior, A. (2006). Człowiek jako racjonalny podmiot działań w świetle założeń koncepcji zrównoważonego rozwoju [Human being as rational subject of actions in the context of sustainable development conception]. Problemy Ekorozwoju, vol. 1(2), pp. 67-72.

12. Kuzior, A. (2008a). Dialog międzykulturowy a koncepcja zrównoważonego rozwoju [Intercultural dialogue and the concept of sustainable development]. In: R. St'ahel, 
Z. Plasienkova (eds.), Histiricke a sucasne podoby myslenia a komunikacie (pp. 236-241). Bratysława.

13. Kuzior, A. (2008b). Paradygmat odpowiedzialności w perspektywie koncepcji sustainable development [The paradigm of responsibility in the perspective of the concept of sustainable development]. In: V. Gluchman (ed.), Moralka a sucasnost (pp. 88-96). Preszów.

14. Kuzior, A. (2008c). Sprawiedliwość pokoleniowa i międzypokoleniowa w kontekście założeń koncepcji zrównoważonego rozwoju [Generational and intergenerational justice in the context of the assumptions of the concept of sustainable development]. In: D. Probucka (ed.), Czy sprawiedliwość jest możliwa? (pp. 333-339). Kraków.

15. Kuzior, A. (2014). Aksjologia zrównoważonego rozwoju [Axiology of sustainable development]. Bańska Bystrzyca.

16. Kuzior, A., Knosala, B. (2015). Changes in perception and implementation of CSR in the Polish enterprises. Zeszyty Naukowe Politechniki Ślaskiej Organizacja i Zarzadzanie, z. 81, pp. 119-129.

17. Kuzior, A., Kwilinski, A., Tkachenko, V. (2019). Sustainable development of organizations based on the combinatorial model of artificial intelligence. Entrepreneurship and Sustainability, 7(2).

18. Kuzior, A., Zozul'ak, J. (2019). Adaptation of the Idea of Phronesis in Contemporary Approach to Innovation. Management Systems in Production Engineering, 27(2), pp. 84-87.

19. Kwilinski, A., Kuzior, A. (2020). Cognitive technologies in the management and formation of directions of the priority development of industrial enterprises. Management Systems in Production Engineering, 28(2), pp. 133-138.

20. Kwilinski, A., Tkachenko, V., Kuzior, A. (2019). Transparent cognitive technologies to ensure sustainable society development. Journal of Security and Sustainability Issues, 9(2), pp. 561-570.

21. Łobocki, M. (2005). Teoria wychowania w zarysie [Outline theory of education]. Kraków.

22. Maciejewski, M. (2012). Szkic z dziejów idei sprawiedliwości od czasów starożytnych do wspótczesności $i$ Sketch of the history of the idea of justice from ancient times to the present day], http://www.repozytorium.uni.wroc.pl/Content/41099/01_Marek_Maciejewski.pdf.

23. Meadows, D.H. et al. (1972). The Limits to Growth; A Reportfor the Club of Rome's. Project on the Predicament of Mankind. New York.

24. Orbik, Z., Zozul'aková, V. (2019). Corporate social and digital responsibility. Management Systems in Production Engineering, 27(2), pp. 79-83.

25. Our Common Future (1987). World Commission on Environment and Development, Oxford University Press, Oxford-New-York. 
26. Przyszłość jakiej chcemy, http://www.mos.gov.pl/g2/big/2012_12/927b84fcb58c51d3731bd08dc2ff700d.pdf, http://odpowiedzialnybiznes.pl/public/files/Analiza_tematyczna_3_Rio+20.pdf.

27. Raport ONZ: Głód wciąż zagraża milionom ludzi na świecie [UN Report: Hunger still threatens millions of people around the world] (2018). https://www.unicef.pl/Centrumprasowe/Informacje-prasowe/Raport-ONZ-Glod-wciaz-zagraza-milionom-ludzi-naswiecie.

28. Ropohl, G. (1999). Etyka techniki. In: A. Kiepas (ed.), Człowiek, technika, środowisko. Człowiek współczesny wobec wyzwań końca wieku (pp. 93-107). Katowice.

29. Štrbová, M., Kuzior, P. (2019). Safety management in the age of internet threats. Management Systems in Production Engineering, 27(2), pp. 88-92.

30. Tatarkiewicz, W. (1988). Historia filozofii [History of Philosophy], t. 1. Warszawa.

31. The future we want, https://sustainabledevelopment.un.org/content/documents/ 733FutureWeWant.pdf.

32. Tkachenko, V., Kuzior, A., Kwilinski, A. (2019). Introduction of artificial intelligence tools into the training methods of entrepreneurship activities. Journal of Entrepreneurship Education, 22(6), 1-10. Retrieved from https://www.abacademies.org/articles/Introductionof-artificial-intelligence-tools-1528-2651-22-6-477.pdf.

33. Zozul'aková, V. (2018). Value of Humanities and Humanities Research. Exploring the Influence of Byzantine Value System in Slavic Environment. Zeszyty Naukowe Politechniki Śląskiej Organizacja i Zarządzanie, z. 122, pp. 221-228.

34. Żuk, G. (2016). Edukacja aksjologiczna. Zarys problematyki [Axiological education. Outline of issues]. Lublin. 